\title{
Use of the TOPSIS technique to choose the best supplier of quarry natural aggregate
}

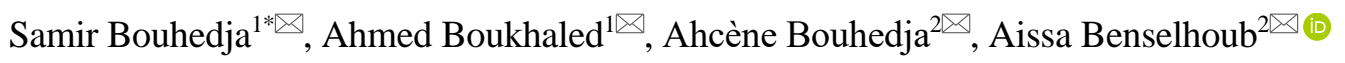 \\ ${ }^{1}$ University of Sciences and Technology, Houari Boumediène, Algiers, 16111, Algeria \\ ${ }^{2}$ Badji Mokhtar University, Annaba, 23000, Algeria \\ *Corresponding author: e-mail bouhedja18@gmail.com, tel.+213671627830
}

\begin{abstract}
Purpose. All over the world, natural substance - the most consumed after water - is the aggregate. The aim of this paper is to select the best supplier of Quarry Natural Aggregate (QNA).
\end{abstract}

Methods. Selection of the best supplier of QNA is performed using the TOPSIS (Technique for Order Preference by Similarity to Ideal Solution) approach, and the method of weights based on ordinal ranking of criteria, and Lagrange multiplier.

Findings. In this article, the proposed Multi-Criteria Decision Making (MCDM) approach helps the decision maker(s) to choose the best supplier of QNA amongst the considered and evaluated suppliers.

Originality. During negotiation with suppliers, many are the decision makers which only attach an importance at two criteria (unit price and quality, or unit price and delivery time). Thereby, other criteria are not taken into account. Consequently, supplier selection would become not-efficient. The originality of this work is based on the multi-criteria approach to choose the best supplier of QNA.

Practical implications. The efficient choice of the best supplier of QNA represents a practical and economical value for the enterprises of the civil engineering, public works, railway and hydraulic works.

Keywords: lagrange multiplier, criteria weights, TOPSIS, supplier, aggregate, quarry

\section{Introduction}

Supplier selection problem of Quarry Natural Aggregate (QNA) is delicate. It is inter alia posed to the Enterprises of civil engineering, public works, bridges-and-roadways, construction of hydraulic dams, and railway.

Novelty of this article is the application of multi-criteria approach for choosing the best supplier of QNA. In the proposed methodology, as multi-criteria aggregation procedure, we propose the Technique for Order Preference by Similarity to Ideal Solution (TOPSIS) technique [1]. About the elicitation of criteria weights, we suggest the method of weights based on ordinal ranking of criteria, and Lagrange multiplier [2]. Decisional problems, resolved by the multi-criteria approach, are formalized by criteria as various as conflictual (not having the same units of measurement).

For identifying and defining the criteria to solve QNA supplier selection problem, we undertook a survey near construction and public works' enterprises in Algeria. After recapitulation and analysis of the collected responses, the retained criteria are:

- acquisition price per ton;

- transport price per ton per $\mathrm{km}$;

- transport distance;

- quality;
- delivery time;

- guarantee policy;

- rejection level.

Among the seven criteria above-cited, one criterion (guarantee policy) is qualitative, six other criteria are quantitative. Conversion of the guarantee policy criterion, into quantitative criterion, is realized according to the recommendations of Bellut [3].

In this paper, a numerical example is accomplished to illustrate the proposed methodology. It is stated as follows: "select one supplier of QNA among a set of seven alternatives $\left\{a_{1}, \ldots, a_{7}\right\}$ associated with seven criteria $\left\{C_{1}, \ldots, C_{7}\right\}$ ". After aggregation of the considered alternatives' evaluations, final result indicates that the supplier of QNA $\left\{a_{4}\right\}$ represents the best solution.

\section{Types of aggregates}

Since the advent of industrialization at the beginning of the eighteenth century, aggregates are used in different domains such as civil engineering, bridges-and-roadways, construction of the hydraulic dams, railway, etc. Over twenty billions of tons of aggregates are yearly employed in the world for:

- hydraulic concretes;

- asphaltic concretes; 
- bituminous mixes;

- pavements;

- railway (as ballast);

- surface treatment;

- abrasives; etc.

Aggregates generally come from two different sources: natural aggregates and artificial aggregates:

1. The natural aggregates are extracted from the sand deposits, the gravel deposits and the quarries. They are divided as follows:

- river aggregate (sand);

- sea aggregate (marine sand);

- lake aggregate (sand);

- desert aggregate (eolian sand);

- glacial aggregate (sand);

- fluvial aggregate (sand);

- quarries' aggregates.

Concerning the aggregates of quarries, they are divided as follows [4]:

a) aggregates of calcareous origin: caliche, marl, coquina, limestone, dolomite;

b) aggregates of siliceous origin: flint, agate, chalcedony, chert, opal;

c) aggregates obtained starting from the metamorphic rocks: marble, gneiss, schist, quartzite, slate;

d) aggregates obtained starting from the igneous rocks: basalt, diorite, andesite, granite, and gabbro.

2. The artificial aggregates, which are of mineral origin emanating from an industrial treatment, can be slags, residues of mines and quarries, ashes and waste of bricks. There is equally another category of artificial aggregates. It is about the recycled and developed aggregates starting from the demolition of old constructions [5].

A natural aggregate, before its exploitation, must obligatorily satisfy standards of use which are generally required before the quarry is certified and authorized for production.

\section{Problematic of suppliers' selection}

A supplier is defined as being an executant of services in accordance with the schedule of conditions which inter alia specifies his duties and the rights of customer(s).

Services carried out by the suppliers are numerous, they concern the sale of materials, minerals, equipments, products, etc.; the repair of defective machines; the provisioning of the companies of spare parts; etc.

In construction and public works' sector, local enterprises or multinational corporations often pass contracts with one or more suppliers to be supplied by one or more products necessary to the realization of works.

By way of illustration, one Unit of works prefabrication in concrete (beams, attic-windows, cornices, longitudinal beams, etc.) is related to several suppliers. Amongst those latter, we can quote: the supplier of cements, the supplier of aggregates, the supplier of equipments, the supplier of electricity, the supplier of natural gas, etc.

The selection of suppliers becomes thus a strategic decision which has a crucial impact on the global performance for any enterprise [6]. The supplier evaluation-selection problem can be solved by using one of methods or approaches below:

1. Method based on the cost.

2. Method based on the artificial intelligence.
3. Method of categorization.

4. Mono-objective mathematical programming method.

5. Multi-objective mathematical programming method.

6. Probabilistic method.

7. Statistical method.

8. Multi-criteria approach with single criterion of synthesis.

9. Multi-criteria approach with outranking of alternatives.

10. Hybrid approach.

Let us note that several researchers consider the supplier selection problem as being of multi-criteria nature [7], [8]. The works relating to the supplier selection, using the multicriteria approach and published those latter years, are numerous and relevant [9].

\section{Overview on the multi-criteria decision making}

\subsection{Criteria weights' elicitation methods}

In the multi-criteria decision making, weights of selection criteria are directly provided by the decision maker or indirectly determined starting from methods of calculation. According to the literature, there are various methods for eliciting criteria weights. The most relevant methods are presented in Table 1 .

\section{Table 1. Main methods of criteria weights' elicitation}

\begin{tabular}{lc}
\hline \multicolumn{1}{c}{ Methods } & Author(s) \\
\hline Method of successive comparisons & Churchmann and Ackoff \\
Method of simple ranking & Kendall (1970) \\
Method of trade-offs & Keeny and Raiffa (1976) \\
Method of eigenvalues & Saaty (1980) \\
Method of reciprocal weights & Stillwell et al. (1981) \\
Method of rank sum linear weights & Fleiss (1981) \\
Method of standard deviation & Zeleny (1982) \\
Method of entropy & Solymosi and Dombi \\
Method of the centralized weights & (1985) \\
& Von Winterfeldet and \\
Method of ratio & Edwards (1986) \\
Method of probabilistic evaluation & Rietveld (1989) \\
Statistical method & Diakoulaki et al. (1992) \\
Method of "resistance to change" grid & Rogers and Bruen (1998) \\
Method of geometrical weights & Lootsma (1999) \\
Method based on the distance & Xu (2001) \\
between partial preorders &
\end{tabular}

between partial preorders

Method of the revised Sismos'

procedure

Method based on the rank

inclusion in criteria hierarchies

Method of empirical weights

Method of total variation

Method of MGDA/Multiple

Gradient Descent Algorithm

Method Q-Eval/Questioning-

Evaluation

Method of KEMIRA/Kemeny

Median Indicator Ranks

Accordance

Method based on the Data

Envelopment Analysis

Method based on the ordinal

ranking of criteria and Lagrange

multiplier
Figueira and Roy (2002)

Salo and Punkka (2005)

Alfares and Duffuaa (2009) (2011)

Désidéri (2012)

Eppe and De Smet (2014)

Krylovas et al. (2014)

Bagherikahvarin and De Smet (2017)

Bouhedja and Pousin (2017)
Bouhedja and Pousin 


\subsection{Multi-Criteria Decision Making methods}

According to the literature, Multi-Criteria Decision Making (MCDM) methods are divided into two categories below:

The first category (belonging to the American school) is composed from the aggregation methods based on a single criterion of synthesis.

The second category (belonging to the European school) is constituted from the aggregation methods based on the outranking of alternatives.

The main methods of multi-criteria decision making are presented in Table 2.

Table 2. Main methods of multi-criteria decision making

\begin{tabular}{|c|c|}
\hline MCDM Methods & Author(s) \\
\hline $\begin{array}{l}\text { SMART (Simple Multi-Attribute } \\
\text { Ranking Technique) method }\end{array}$ & Edwards (1971) \\
\hline $\begin{array}{l}\text { MAUT (Multi-Attribute Utility } \\
\text { Theory) method }\end{array}$ & Keeny and Raiffa (1976) \\
\hline $\begin{array}{l}\text { AHP (Analytical Hierarchy } \\
\text { Process) method }\end{array}$ & Saaty (1980) \\
\hline $\begin{array}{l}\text { TOPSIS (Technique for Order } \\
\text { Preference by Similarity to } \\
\text { Ideal Solution) method }\end{array}$ & Hwang and Yoon (1981) \\
\hline WSM (Weighted Sum Method) & In Timmermann (1986) \\
\hline WPM (Weighted Product Method) & $\begin{array}{l}\text { In Pomerol and } \\
\text { Barba-Romeo (1993) }\end{array}$ \\
\hline $\begin{array}{l}\text { COPRAS (COmplex PRopotional } \\
\text { ASsessment) method }\end{array}$ & Zavadskas et al. (1994) \\
\hline $\begin{array}{l}\text { SIR (Superiority and Inferiority } \\
\text { Ranking) method }\end{array}$ & $\mathrm{Xu}(2001)$ \\
\hline $\begin{array}{l}\text { VIKOR* (VIseKriterijumska } \\
\text { Optimizacija i kompromisno }\end{array}$ & $\begin{array}{l}\text { In Oprocovic and } \\
\text { Tzeng (2004) }\end{array}$ \\
\hline ARAS (Additive Ratio & Zavadskas and Turskis \\
\hline ASsessment) method & $(2010)$ \\
\hline $\begin{array}{l}\text { ARAS-G (Additive Ratio } \\
\text { Assessment-Grey) method }\end{array}$ & $\begin{array}{l}\text { Turskis and Zavadskas } \\
\text { (2010) }\end{array}$ \\
\hline $\begin{array}{l}\text { SAW (Simple Additive } \\
\text { Weighting) method }\end{array}$ & In Afshari et al. (2010) \\
\hline $\begin{array}{l}\text { SWARA (Step-wise Weight } \\
\text { Assessment Ratio Analysis) method }\end{array}$ & Keršuliene et al. (2010) \\
\hline $\begin{array}{l}\text { ELECTRE (ELimination Et Choix } \\
\text { Traduisant la REalité) methods }\end{array}$ & Roy (1996) \\
\hline $\begin{array}{l}\text { PROMETHEE (Preference } \\
\text { Ranking Organization METHod } \\
\text { for Enrichment Evaluation) methods }\end{array}$ & $\begin{array}{l}\text { Brans and Mareschal } \\
\text { (2002) }\end{array}$ \\
\hline
\end{tabular}

*VIKOR: in English means "Multi-criteria optimization and compromise solution"

\section{Proposed methodology}

\subsection{Identification of the selection criteria}

When solving multi-criteria decisional problems, number of criteria is generally given by the decision maker(s). However, for helping as well decision maker(s) than analyst (technical expert), many researchers work on identification of the selection criteria.

The multiple criteria, used in the supplier selection framework, are identified and defined by numerous authors whose [10], [11].

The above-mentioned researchers' results, concerning the identification of criteria in relation to the supplier selection problem, show that the criteria represent strong and indispensible link in the multi-criteria decision making process. However, for each category of suppliers, it is necessary to identify and define the corresponding criteria.
For the supplier selection of quarry natural aggregate, we undertook a survey near construction and public works' enterprises in Algeria. After recapitulation and analysis of the collected responses, we have identified the criteria as shown in Table 3.

Table 3. Identification of the selection criteria

\begin{tabular}{lcc}
\hline$C_{j}$ & Definition of criteria & Ranks \\
\hline$C_{1}$ & Acquisition price per ton & 1 \\
$C_{2}$ & Transport price per ton per km & 2 \\
$C_{3}$ & Transport distance & 3 \\
$C_{4}$ & Quality of QNA & 4 \\
$C_{5}$ & Delivery time & 5 \\
$C_{6}$ & Guarantee policy & 6 \\
$C_{7}$ & Rejection level & 7 \\
\hline
\end{tabular}

Let us look at these criteria in a detailed way. The seven above-mentioned criteria form a family of criteria in relation with the economic and technical domain. This family of criteria satisfies five conditions imposed by Keeny and Raiffa (1976) which are: exhaustivity, non-redundancy, operability, decomposability and minimality.

The two first are criteria strictly economical: the first is related to the acquisition price of QNA, and the second concerns transport price per ton per kilometer.

The third criterion is related to the transport distance. It is considered by the ones as criterion of geographical localization, by others as economical criterion. Let us note that the quarries, which produce the aggregates, are generally far from the activity zones of the enterprises-consumers of QNA. Then, price of transport depends on the hauling distance. It can be higher or exceeds purchase in some cases.

The fourth criterion is technical, it characterizes quality of QNA. Natural aggregates, used for hydraulic concretes, asphaltic concretes or bituminous mixes, must obligatorily satisfy standards of use which are required before the quarries are certified and allowed for production. In this paper, we have retained clay fines' content as criterion of quality. The consequences of the presence of the argillaceous particles, in great quantity in the concrete, are numerous. We can quote for example: the expansion of hardened concrete, appearance of fissures, loss of resistance, and the decrease in durability.

In construction and public works' sector in Algeria, maximum content of clay fines' particles is regulated at 3\% [12]. According to Reza and Wilde [13], maximum allowable percentages of clay lumps and friable particles are 2, 3 and $3 \%$ respectively for the weathering exposure categories: severe, moderate, and negligible.

When silt fines content is more than 5\%, concrete exhibits higher chloride ion penetrability and decreases in durability [14]. In this work, for the criterion of quality of quarry natural aggregate, content of clay fines must not exceed 3\%.

The fifth criterion is technico-temporal. It concerns delivery time. Let us mention that more the delivery time is respected by supplier, more the consumer(s) of QNA is (are) at ease in his (their) work organization. The delivery time can extend from one at some days. It depends on the availability of the quantities produced or stored by every supplier of QNA.

The sixth criterion concerns responsibility of the supplier. It is related to the guarantee policy ensured by supplier towards the customer(s). In this article, we perform the conversion of the guarantee policy criterion into quantitative criterion (Table 4). 
Table 4. Ranks of guarantee policy

\begin{tabular}{ccc}
\hline QNA suppliers' types & Guarantee policy & Ranks, (points) \\
\hline Reliable supplier & Excellent & 5 \\
Credible supplier & Good & 4 \\
Acceptable supplier & Moderate & 3 \\
Recoverable supplier & Weak & 2 \\
Failing supplier & Bad & 1 \\
\hline
\end{tabular}

Conversion of the guarantee policy criterion, into quantitative criterion with five ranks, is accomplished according to the guidelines of Bellut [3]. Then, the five ranks, characterizing fives types of QNA suppliers, are presented as follows:

1. Reliable supplier (5 points): excellent performance, excellent management, excellent technical capacity, excellent turnover, thorough respect of contracts with the customers.

2. Credible supplier (4 points): good performance, good management, good technical capacity, good turnover, sure respect of contracts with the customers.

3. Acceptable supplier ( 3 points): moderate performance, moderate management, moderate technical capacity, moderate turnover, plausible respect of contracts with the customers.

4. Recoverable supplier if improvement will take place in the future ( 2 points): weak performance, weak management, weak technical capacity, weak turnover, possible respect of contracts with the customers.

5. Failing supplier (1 point): supplier in bankruptcy, very weak performance, catastrophic management, very weak technical capacity, unimportant turnover, probable respect of contracts with the customers.

Within the framework of invitation to tender, enterprisecustomer asks every QNA supplier-tenderer to indicate expressly its guarantee policy. Enterprise-customer of QNA checks it in order to determine the rank of every considered supplier according to the Table 4. By using several ways suggested by Building Global Friendship [15].

The proposition, presented in Table 4, can be used for estimating guarantee policy of every considered QNA supplier-tenderer.

The seventh criterion is technico-organizational. It concerns rejection level. This last is determined by the number of orders for the returned QNA to the supplier(s) by enterprise-customer following a doubtful QNA, a QNA polluted by fine particles of dusty or argillaceous origin whose content is higher than 3\%, or in case of a QNA not respecting the standards of use. In this article, we propose that the rejection level is rated every latest three months by basing on the collected information near business acquaintances, or by carrying out chemical and mineralogical tests (for a doubtful QNA), methylene blue test (for a polluted QNA), or geomechanical tests (for a QNA not satisfying standards of use) in the laboratory of the QNA enterprise-consumer itself. Else, at the level of a third laboratory in order to be sure of the tests' results.

\subsection{Proposed method for eliciting the criteria weights}

In this paper, for eliciting criteria weights, we propose the method of weights based on ordinal ranking of criteria, and Lagrange multiplier developed by Bouhedja and Pousin [2]. The proposed method is presented by three steps below:

Step 1. Ask to a decision maker to provide ascending ordinal ranking of criteria.

Step 2. Calculate the Lagrange multiplier $(\lambda)$ :

$$
\lambda=\frac{2}{\left(\sum_{j=1}^{n} \frac{1}{[(n+1)-j]}\right) \cdot[n(n+1)]},
$$

where:

$$
n \text { - number of criteria; }
$$

$j=1, \ldots n(n \geq 3)$.

Step 3. Determine the weight of criterion $j\left(W_{j}\right)$ :

$$
W_{j}=\frac{\lambda[n(n+1)]}{2[(n+1)-j]},
$$

where:

$$
\begin{aligned}
& \lambda \text { - lagrange multiplier; } \\
& n \text {-number of criteria; } \\
& j=1, \ldots n(n \geq 3) .
\end{aligned}
$$

\subsection{Proposed method for multi-criteria decision making}

TOPSIS technique is proposed in this article for the advantages which it has.

\subsubsection{Argumentation of the choice of TOPSIS}

TOPSIS is chosen in this research work for the reasons below:

1. It solves the dilemma relating to the choice of closeness to the positive-ideal solution, or remoteness to the negative-ideal solution.

2. It introduces the concepts of positive-ideal and negative-ideal in multi-criteria decision making.

3. It conforms with a logic of distance minimization to the positive-ideal solution, or with a logic of distance maximization to the negative-ideal solution.

4. It is a specific and operational method as multi-criteria aggregation procedure.

5. It uses three types of distance: i) rectilinear distance (P1); ii) Euclidean distance (P2) and iii) Tchebycheff distance $(\mathrm{P} \infty)$. According to Olsen [16], the best result is obtained by Euclidean distance.

6 . It permits to identify quickly best solution when aggregation of the alternatives' performances' values.

7. It finds broad application in various domains. Several articles, using the TOPSIS approach, are already published [17], [18].

\subsubsection{Presentation of TOPSIS}

TOPSIS approach assumes that we have: " $m$ " alternatives and " $n$ " criteria, and the performance value " $a_{i j}$ " of each alternative $i(i=1, \ldots, m)$ with the respect of criterion $j$ $(j=1, \ldots, n(n \geq 3))$.

TOPSIS is developed by Hwang and Yoon, it only admits selection criteria of quantitative type. TOPSIS is partially compensatory and presented by the following steps [1]:

Step 1. Calculate the normalized decision matrix. The normalized value $r_{i j}$ is calculated as in expression (3):

$$
r_{i j}=\frac{a_{i j}}{\sqrt{\sum a_{i j}{ }^{2}}},
$$

where:

$$
\begin{aligned}
& i=1, \ldots m \\
& j=1, \ldots n
\end{aligned}
$$


The normalized decision matrix $\left(R:=r_{i j}\right)$ is presented below:

$$
R:=r_{i j}\left[\begin{array}{cccc}
r_{11} & r_{12} & \ldots & r_{1 n} \\
r_{21} & r_{22} & \ldots & r_{2 n} \\
\ldots & \ldots & \ldots & \ldots \\
r_{m 1} & r_{m 2} & \ldots & r_{m n}
\end{array}\right] .
$$

Step 2. Calculate the weighted normalized decision matrix. The weighted normalized value $v_{i j}$ is calculated as in expression (5):

$v_{i j}=W_{j} \cdot r_{i j}$

where:

$i=1, \ldots m$;

$j=1, \ldots n$.

A set of weights $W=\left[W_{1}, \ldots, W_{n}\right]$ (satisfying $\left.\sum_{j=1}^{n} W_{j}=1\right)$ defined by the decision maker is accommodated to the decision matrix to generate the weighted normalized decision matrix $\left(V:=v_{i j}\right)$ :

$V:=v_{i j}\left[\begin{array}{cccc}W_{1} r_{11} & W_{2} r_{12} & \ldots & W_{n} r_{1 n} \\ W_{1} r_{21} & W_{2} r_{22} & \ldots & W_{n} r_{2 n} \\ \ldots & \ldots & \ldots & \ldots \\ W_{1} r_{m 1} & W_{2} r_{m 2} & \ldots & W_{n} r_{m n}\end{array}\right]$.

Step 3. The positive-ideal $A^{+}$and the negative-ideal $A^{-}$solutions are defined as follows:

$$
\begin{aligned}
& A^{+}=\left\{\max _{j} v_{i j}, j \in J ; \min _{j} v_{i j}, j \in J^{\prime}\right\} ; \\
& A^{-}=\left\{\min _{j} v_{i j}, j \in J ; \max _{j} v_{i j}, j \in J^{\prime}\right\} .
\end{aligned}
$$

For the benefit criteria $J$, the decision maker wants to have a maximum value among the alternatives. For the cost criteria $J^{\prime}$, the decision maker wants to have a minimum value among the alternatives.

Obviously, $A^{+}$indicates the most preferable alternative or ideal solution. Similarly, $A^{-}$indicates the least preferable alternative or negative-ideal solution.

Step 4. Calculate the separation measure. In this step, the concept of the $N$-dimensional Euclidean distance is used to measure the separation distances of each alternative $a_{i}$ to the ideal solution and negative-ideal solution. In expression (9), $S^{+}{ }_{a i}$ (distance to the ideal solution) and $S^{-}{ }_{a i}$ (distance to the negative-ideal solution) are calculated with given formula:

$$
\begin{aligned}
& S_{a_{i}}^{+}=\sqrt{\left[\sum\left(v_{i j}-A_{i}^{+}\right)^{2}\right]} ; \\
& S_{a_{i}}^{-}=\sqrt{\left[\sum\left(v_{i j}-A_{j}^{-}\right)^{2}\right]},
\end{aligned}
$$

where:

$$
\begin{aligned}
& i=1, \ldots, m ; \\
& j=1, \ldots, n .
\end{aligned}
$$

Step 5. Calculate the relative closeness to the ideal solution. The relative closeness of the alternative $a_{i}\left(C_{a i}^{*}\right)$ with the respect $A^{+}$is defined as in expression (11):

$$
C_{a_{i}}^{*}=\frac{S_{a_{i}}^{-}}{S_{a_{i}}^{-}+S_{a_{i}}^{+}}, 0 \leq C_{a_{i}}^{*} \leq 1 .
$$

Step 6. After sorting the $C^{*}{ }_{a i}$ values, the maximum value corresponds to the best solution to the problem. The previous definition can also be used to demonstrate that any alternative which has the shortest distance from the ideal solution is also guaranteed to have the longest distance from the negative-ideal solution.

\section{Numerical example}

A Construction Enterprise (C.E.) launches an invitation to tender for selecting one supplier of QNA. The schedule of conditions, placed at the disposal of the tenderers by the C.E., inter alia stipulates that:

The requested aggregate must be manufactured starting from the limestone and must have a content of clay fines lower or equal to $3 \%$.

The selection criteria of the suppliers of QNA are established as follows:

i) acquisition price per ton $\left(C_{1}\right)$; ii) transport price per ton per kilometer $\left(C_{2}\right)$; iii) transport distance $\left(C_{3}\right)$; iv) quality of QNA $\left.\left(C_{4}\right) ; \mathrm{v}\right)$ delivery time $\left(C_{5}\right)$; vi) guarantee policy $\left(C_{6}\right)$,

\begin{tabular}{|c|c|c|c|c|c|c|c|}
\hline \multirow{4}{*}{$\begin{array}{c}\text { Suppliers } \\
\text { of QNA } \\
a_{i}\end{array}$} & \multicolumn{7}{|c|}{ Selection criteria $C_{j}$} \\
\hline & $C_{1}$ & $C_{2}$ & $C_{3}$ & $C_{4}$ & $C_{5}$ & $C_{6}$ & $C_{7}$ \\
\hline & $\mathrm{DA} / \mathrm{t}$ & $\mathrm{DA} / \mathrm{t} / \mathrm{km}$ & $\mathrm{km}$ & $\%$ & Day & - & - \\
\hline & $\min$ & $\min$ & $\min$ & $\min$ & $\min$ & $\max$ & $\min$ \\
\hline$a_{1}$ & 4000 & 125 & 25 & 3 & 1 & Moderate & 3 \\
\hline$a_{2}$ & 3850 & 140 & 24 & 2 & 4 & Good & 1 \\
\hline$a_{3}$ & 3800 & 135 & 15 & 3 & 4 & Moderate & 2 \\
\hline$a_{4}$ & 4100 & 120 & 10 & 1 & 2 & Excellent & 0 \\
\hline$a_{5}$ & 4250 & 150 & 12 & 3 & 5 & Good & 2 \\
\hline$a_{6}$ & 4200 & 145 & 18 & 2 & 1 & Moderate & 3 \\
\hline$a_{7}$ & 3950 & 130 & 20 & 3 & 3 & Good & 1 \\
\hline
\end{tabular}
and vii) rejection level $\left(C_{7}\right)$.

The financial and technical offers, proposed by the suppliers-tenderers, are presented in Table 5. For solving this problem, we apply the methodology proposed in this article.

Table 5. Original decision matrix A (relating to the supplier selection of QNA)

*DA: Algerian Dinar (Currency of Algeria).

\subsection{Final results}

\subsubsection{Conversion of the guarantee policy criterion}

The guarantee policy criterion must be converted into quantitative criterion. For that, we use the ranks proposed in Table 4. Then, we assign for moderate guarantee policy: (3 points); good guarantee policy: (4 points), and excellent guarantee policy: (5 points). The obtained values are inserted in their respective places at the level of the column of criterion $C_{6}$ (Table 6).

\subsubsection{Normalized decision matrix $R$}

The result of normalization of the considered suppliers' performances' values is presented in Table 7 .

\subsubsection{Result of the criteria weights}

The criteria weights, elicited according to the method based on ordinal ranking of criteria, and Lagrange multiplier, are shown in Table 8. 
Table 6. Original decision matrix A (all the considered criteria are quantitative)

\begin{tabular}{|c|c|c|c|c|c|c|c|}
\hline \multirow{3}{*}{$\begin{array}{c}\text { Suppliers } \\
\text { of QNA } \\
a_{i}\end{array}$} & \multicolumn{7}{|c|}{ Selection criteria $C_{j}$} \\
\hline & $C_{1}$ & $\overline{C_{2}}$ & $C_{3}$ & $C_{4}$ & $C_{5}$ & $C_{6}$ & $C_{7}$ \\
\hline & $\mathrm{DA} / \mathrm{t}$ & $\mathrm{DA} / \mathrm{t} / \mathrm{km}$ & $\mathrm{km}$ & $\%$ & Day & - & - \\
\hline & & & 11111 & & 11111 & IIIax & \\
\hline$a_{1}$ & 4000 & 125 & 25 & 3 & 1 & 3 & 3 \\
\hline$a_{2}$ & 3850 & 140 & 24 & 2 & 4 & 4 & 1 \\
\hline$a_{3}$ & 3800 & 135 & 15 & 3 & 4 & 3 & 2 \\
\hline$a_{4}$ & 4100 & 120 & 10 & 1 & 2 & 5 & 0 \\
\hline$a_{5}$ & 4250 & 150 & 12 & 3 & 5 & 4 & 2 \\
\hline$a_{6}$ & 4200 & 145 & 18 & 2 & 1 & 3 & 3 \\
\hline$a_{7}$ & 3950 & 130 & 20 & 3 & 3 & 4 & 1 \\
\hline
\end{tabular}

*Min means criterion to be minimized and max means criterion to be maximized

Table 7. Normalized decision matrix $R$

\begin{tabular}{cccccccc}
\hline \multirow{2}{*}{$\begin{array}{c}\text { Suppliers } \\
\text { of QNA }\end{array}$} & \multicolumn{7}{c}{ Selection criteria $C_{j}$} \\
\cline { 2 - 8 }$a_{i}$ & $C_{1}$ & $C_{2}$ & $C_{3}$ & $C_{4}$ & $C_{5}$ & $C_{6}$ & $C_{7}$ \\
\hline$a_{1}$ & 0.3756 & 0.3490 & 0.5109 & 0.4472 & 0.1178 & 0.3000 & 0.5669 \\
$a_{2}$ & 0.3615 & 0.3908 & 0.4905 & 0.2981 & 0.4714 & 0.4000 & 0.1889 \\
$a_{3}$ & 0.3568 & 0.3769 & 0.3065 & 0.4472 & 0.4714 & 0.3000 & 0.3779 \\
$a_{4}$ & 0.3850 & 0.3350 & 0.2043 & 0.1490 & 0.2357 & 0.5000 & 0 \\
$a_{5}$ & 0.3991 & 0.4188 & 0.2452 & 0.4472 & 0.5892 & 0.4000 & 0.3779 \\
$a_{6}$ & 0.3944 & 0.4048 & 0.3678 & 0.2981 & 0.1178 & 0.3000 & 0.5669 \\
$a_{7}$ & 0.3709 & 0.3629 & 0.4087 & 0.4472 & 0.3535 & 0.4000 & 0.1889 \\
\hline
\end{tabular}

Table 8. Result of the criteria weights

\begin{tabular}{cccc}
\hline \multirow{2}{*}{$\begin{array}{c}\text { Criteria } \\
C_{j}\end{array}$} & Definition of criteria & \multicolumn{2}{c}{$\begin{array}{c}\text { Weights } \\
\text { of criteria }\end{array}$} \\
\cline { 3 - 4 } & & $W_{j}$ & Values \\
\hline$C_{1}$ & Acquisition price per ton & $W_{1}$ & 0.3856 \\
$C_{2}$ & Transport price per ton per kilometer & $W_{2}$ & 0.1928 \\
$C_{3}$ & Transport distance & $W_{3}$ & 0.1286 \\
$C_{4}$ & Quality of QNA & $W_{4}$ & 0.0964 \\
$C_{5}$ & Delivery time & $W_{5}$ & 0.0772 \\
$C_{6}$ & Guarantee policy & $W_{6}$ & 0.0643 \\
$C_{7}$ & Rejection level & $W_{7}$ & 0.0551 \\
\hline
\end{tabular}

\subsubsection{Weighted normalized decision matrix $\mathrm{V}$}

The weighted normalized decision matrix, according to the TOPSIS technique, is presented in Table 9.

Table 9. Weighted normalized decision matrix $V$

\begin{tabular}{cccccccc}
\hline Suppliers & \multicolumn{7}{c}{ Selection criteria $C_{j}$} \\
\cline { 2 - 8 } of QNA & $C_{1}$ & $C_{2}$ & $C_{3}$ & $C_{4}$ & $C_{5}$ & $C_{6}$ & $C_{7}$ \\
$a_{i}$ & min & min & min & min & $\min$ & $\max$ & $\min$ \\
\hline$a_{1}$ & 0.1448 & 0.0672 & 0.0657 & 0.0431 & 0.0090 & 0.0192 & 0.0312 \\
$a_{2}$ & 0.1393 & 0.0753 & 0.0630 & 0.0287 & 0.0363 & 0.0257 & 0.0104 \\
$a_{3}$ & 0.1375 & 0.0726 & 0.0394 & 0.0431 & 0.0363 & 0.0192 & 0.0208 \\
$a_{4}$ & 0.1484 & 0.0645 & 0.0262 & 0.0143 & 0.0181 & 0.0321 & 0 \\
$a_{5}$ & 0.1538 & 0.0807 & 0.0315 & 0.0431 & 0.0454 & 0.0257 & 0.0208 \\
$a_{6}$ & 0.1520 & 0.0780 & 0.0472 & 0.0287 & 0.0090 & 0.0192 & 0.0312 \\
$a_{7}$ & 0.1430 & 0.0699 & 0.0525 & 0.0431 & 0.0272 & 0.0257 & 0.0104 \\
\hline
\end{tabular}

\subsubsection{Positive-ideal and negative-ideal solutions}

For each considered criterion, the positive-ideal $A^{+}$and negative-ideal $A^{-}$solutions, according to the TOPSIS technique, are presented in Table 10.

\section{Table 10. Positive-ideal and negative-ideal solutions}

\begin{tabular}{cccccccc}
\hline Positive-ideal & \multicolumn{7}{c}{ Selection criteria $C_{j}$} \\
\cline { 2 - 8 } $\begin{array}{c}\text { and negative- } \\
\text { ideal solutions }\end{array}$ & $\begin{array}{c}C_{1} \\
\mathrm{~min}\end{array}$ & $\begin{array}{c}C_{2} \\
\mathrm{~min}\end{array}$ & $\begin{array}{c}C_{3} \\
\mathrm{~min}\end{array}$ & $\begin{array}{c}C_{4} \\
\mathrm{~min}\end{array}$ & $\begin{array}{c}C_{5} \\
\min \end{array}$ & $\begin{array}{c}C_{6} \\
\max \end{array}$ & $\begin{array}{c}C_{7} \\
\min \end{array}$ \\
\hline$A^{+}$ & 0.1375 & 0.0645 & 0.0262 & 0.0143 & 0.0090 & 0.0321 & 0 \\
$A^{-}$ & 0.1538 & 0.0807 & 0.0657 & 0.0431 & 0.0454 & 0.0192 & 0.0312 \\
\hline
\end{tabular}

\subsubsection{Result of evaluation of the QNA suppliers}

The result of evaluation of the considered QNA suppliers, according to the TOPSIS technique, is presented in Table 11.

\subsubsection{Result of ranking of the QNA suppliers}

The result of ranking of the considered QNA suppliers, according to the TOPSIS technique, is shown in Table 12.

The obtained ranking of the considered QNA suppliers is established as follows:

$$
a_{4}>a_{6}>a_{7}>a_{3}>a_{1}>a_{5}>a_{2},
$$

\section{Table 11. Evaluation result of the QNA suppliers}

\begin{tabular}{cccc}
\hline $\begin{array}{c}\text { Suppliers of QNA } \\
a_{i}\end{array}$ & $S^{+}{ }_{a i}$ & $S^{-}{ }_{a i}$ & $C^{*}{ }_{a i}$ \\
\hline$a_{1}$ & 0.0574 & 0.0374 & 0.3945 \\
$a_{2}$ & 0.0489 & 0.0282 & 0.3657 \\
$a_{3}$ & 0.0458 & 0.0300 & 0.3957 \\
$a_{4}$ & 0.0100 & 0.0648 & 0.8663 \\
$a_{5}$ & 0.0538 & 0.0346 & 0.3914 \\
$a_{6}$ & 0.0435 & 0.0424 & 0.4935 \\
$a_{7}$ & 0.0424 & 0.0316 & 0.4270 \\
\hline
\end{tabular}

Table 12. Ranking result of the QNA suppliers

\begin{tabular}{ccc}
\hline $\begin{array}{c}\text { Suppliers of QNA } \\
a_{i}\end{array}$ & $C^{*}{ }^{*}$ & Ranking \\
\hline$a_{4}$ & 0.8663 & 1 \\
$a_{6}$ & 0.4935 & 2 \\
$a_{7}$ & 0.4270 & 3 \\
$a_{3}$ & 0.3957 & 4 \\
$a_{1}$ & 0.3945 & 5 \\
$a_{5}$ & 0.3914 & 6 \\
$a_{2}$ & 0.3657 & 7 \\
\hline
\end{tabular}

The usage of the proposed methodology has enabled us to select the alternative $\left\{a_{4}\right\}$ as being best supplier of quarry natural aggregate amongst the considered and evaluated suppliers (Tables 11 and 12).

\section{Conclusions}

At the end of this research work, the conclusions, which we drew, are presented below.

The resolution of the suppliers' selection problems constitutes an evident importance not only for the decision maker(s), but also for the researchers. According to the literature, several articles, concerning the suppliers' selection, are published those latter years (see www.biblio.prometheegaia.net).

In this article, the proposed methodology is constituted from two parts:

1) elicitation of the criteria weights is performed by using the method of weights based on ordinal ranking of criteria, and Lagrange multiplier;

2) multi-criteria aggregation-evaluation of the performances of the QNA suppliers is realized by using the TOPSIS technique. Although TOPSIS is relatively old, it remains until the day of today usable for solving multicriteria decisional problems in different domains.

The proposed methodology is easy to use. Whoever, having a basic level in mathematics, and having worked on software Excel, can use it.

By way of illustration, the proposed methodology is applied to the numerical example. It has enabled us: 
- elicitation of the criteria weights (Table 8);

- evaluation of the performances' values of each QNA supplier considered (Table 11);

- establishment of the ranking of the QNA suppliers considered (Table 12);

- selection of the alternative $\left\{a_{4}\right\}$ as being best supplier of QNA (Tables 11 and 12).

In the numerical example, Construction Enterprise, as decision maker, can select the supplier $\left\{a_{4}\right\}$ in order to solve the problem of supply in QNA.

In the real-world, any decision maker or technical expert, concerned by the provisioning problem in QNA, can resolve it by using the methodology proposed in this paper.

The future extension of this research work consists to compare the proposed methodology with other approaches for the supplier selection of quarry natural aggregate.

\section{Acknowledgements}

The authors thank all the colleagues which have contributed to the realization of this research work.

\section{References}

[1] Genc, T. (2014). Sensitivity analysis on PROMETHEE and TOPSIS weights. International Journal of Management and Decision Making, 13(4), 403-421. https://doi.org/10.1504/ijmdm.2014.065359

[2] Bouhedja, A., \& Pousin, J. (2017). A new method for determining the weights in multi-criteria decision making based on ordinal ranking of criteria and Lagrange multiplier. Metallurgical and Mining Industry, 5(1), 22-31.

[3] Bellut, S. (2002). Les processus de la décision: méthodes et outils. Saint-Denis, France: Édition AFNOR.

[4] Tutumluer, E., Moaveni, M., \& Qamhia, I.I.A. (2018). Aggregates quality requirements for pavements. Washington, United States: National Academics Press.

[5] Bennert, T., Papp, W.J., Maher, A., \& Gucunski, N. (2000). Utilization of construction and demolition debris under traffic-type loading in base and subbase applications. Transportation Research Record: Journal of the Transportation Research Board, 1714(1), 33-39. https://doi.org/10.3141/1714-05

\section{Використання багатокритеріального методу TOPSIS для вибору кращого постачальника природного заповнювача кар'єру}

\section{С. Бухеджа, А. Бухалед, А. Бухеджа, А. Бенсельгуб}

Мета. Обгрунтування та вибір оптимального постачальника кар'єрного щебню як природного заповнювача на основі використання багатокритеріального методу.

Методика. Вибір найкращого постачальника кар'єрного природного заповнювача здійснювався за допомогою багатокритеріального методу аналізу варіантів за ступенем близькості до оптимального (TOPSIS) і методу вагових коефіцієнтів на основі порядкового ранжирування критеріїв та множника Лагранжа.

Результати. Підхід, що описується в статті, заснований на багатокритеріальному прийнятті рішень і дозволяє обрати кращого постачальника природного заповнювача серед наявних та розглянутих на ринку компаній. В якості ілюстрації запропонована методологія застосована до чисельного прикладу. Це дозволило визначити вагу впливових на оцінку критеріїв, оцінку значень характеристик кожного розглянутого постачальника QNA, встановлення рейтингу розглянутих постачальників QNA і вибір альтернативи $\{a 4\}$ в якості кращого постачальника QNA.

Наукова новизна. Вперше для вибору оптимального постачальника природного заповнювача крім факторів ціни і якості встановлено характер впливу на загальну оцінку також ряду інших факторів: вартість транспортування, транспортна відстань, час доставки, гарантійна політика й рівень відхилення. У даній роботі вперше пропонується багатокритеріальний підхід до вибору оптимального постачальника природного заповнювача кар'єра.

Практична значимість. Ефективний вибір постачальника природного заповнювача кар'єра важливий з практичної та економічної точок зору для підприємств у галузі цивільного будівництва, громадських робіт, залізниці та гідротехнічних споруд.

Ключові слова: множник Лагранжа, метод вагових коефічієнтів, TOPSIS, постачальник, щзебінь, кар'єр

\section{Использование многокритериального метода TOPSIS для выбора лучшего поставщика природного заполнителя карьера}

\section{С. Бухеджа, А. Бухалед, А. Бухеджа, А. Бенсельгуб}

Цель. Обоснование и выбор оптимального поставщика карьерного щебня как природного заполнителя на основе использования многокритериального метода. 
Методика. Выбор лучшего поставщика карьерного природного заполнителя осуществлялся с помощью многокритериального метода анализа вариантов по степени близости к оптимальному (TOPSIS) и метода весовых коэффициентов на основе порядкового ранжирования критериев и множителя Лагранжа.

Результаты. Подход, описываемый в статье, основан на многокритериальном принятии решений и позволяет выбрать лучшего поставщика природного заполнителя среди имеющихся и рассматриваемых на рынке компаний. В качестве иллюстрации предложенная методология применена к числовому примеру. Это позволило определить вес влияющих на оценку критериев, оценку значений характеристик каждого рассматриваемого поставщика QNA, установление рейтинга рассматриваемых поставщиков QNA и выбор альтернативы $\left\{a_{4}\right\}$ в качестве лучшего поставщика QNA.

Научная новизна. Впервые для выбора оптимального поставщика природного заполнителя кроме факторов цены и качества установлен характер влияния на общую оценку также ряда других факторов: стоимость транспортирования, транспортное расстояние, время доставки, гарантийная политика и уровень отклонения. В данной работе впервые предлагается многокритериальный подход к выбору оптимального поставщика природного заполнителя карьера.

Практическая значимость. Эффективный выбор поставщика природного заполнителя карьера важен с практической и экономической точек зрения для предприятий в области гражданского строительства, общественных работ, железной дороги и гидротехнических сооружений.

Ключевые слова: множитель Лагранжа, метод весовых коэффициентов, TOPSIS, поставщик, щебень, карьер

\section{Article info}

Received: 5 February 2019

Accepted: 10 January 2020

Available online: 3 February 2020 